ATUALIZAÇÃO

\title{
HISTÓRIA DA MEDICINA \\ A VARÍOLA NO BRASIL COLONIAL \\ (SÉCULOS XVI E XVII)
}

\section{Cristina Brandt Friedrich Martin Gurgel e Camila Andrade Pereira da Rosa ${ }^{1}$}

\section{RESUMO}

Parte inseparável e tenaz da vida animal, as doenças infecciosas acompanharam e moldaram a história do homem na terra, sobretudo quando começou a viver em aglomerados. No Novo Mundo, com a chegada dos europeus, manifestaram-se como a "guerra biológica da conquista". Atingindo uma população indígena imunologicamente incapaz de combatê-las, a gripe, o sarampo e a varíola selaram o destino de milhões. Neste estudo, objetivamos relatar a catástrofe que representou a varíola para o Brasil, visto que matou de $30 \%$ a $50 \%$ de suas vítimas indígenas, desestruturou toda a sociedade nativa, causou danos imensos à economia colonial e fomentou o tráfico negreiro.

DESCRITORES: História da Medicina. Varíola. Indígenas. Brasil Colonial.

\begin{abstract}
Smallpox in Brazilian Colonial Ages (16th and 17th Centuries)

Infectious diseases, which are part and parcel of animal life, have accompanied and shaped human history on earth, especially since man began to live in clusters. In the New World, with the arrival of the Europeans, they manifested as a "biological war of conquest". Hitting a native population immunologically incapable of resisting them, influenza, measles and smallpox sealed the fate of millions. The aim of this paper is to recount the catastrophe that smallpox represented in the early history of Brazil, where it killed 30 to $50 \%$ of native american victims, destroyed indigenous society, caused immense damage to colonial economy, and promoted slave traffic.
\end{abstract}

KEY WORDS: History of Medicine. Smallpox. Indians. Brazilian Colonial Ages.

1 Centro de Ciências da Vida, Pontifícia Universidade Católica de Campinas, Campinas, São Paulo.

Endereço para correspondência: Cristina B F M Gurgel, Rua MMDC, n 47, apto 101, Campinas, São Paulo, CEP 13025-139, Brasil. E-mail: cbfmgurgel@ig.com.br

Recebido para publicação em: 15/5/2012. Aceito em: 30/10/2012. 


\section{INTRODUÇÃO}

Desde os primórdios de sua existência, os homens buscaram vencer os desafios que a fragilidade física lhes impunha. As doenças, consideradas como reflexos de crenças, costumes e da organização social dos povos, por eles foram analisadas, sentidas e combatidas de maneiras diferentes (19). Em comum, existia um apurado senso de observação sobre as enfermidades: se eram autolimitadas ou crônicas, se contagiosas e passíveis de alguma forma de controle e, sobretudo, se podiam ser combatidas. A terapêutica, meramente empírica, era apenas uma consequência desta percepção e valia-se de análises legítimas sobre condutas de higiene ou do emprego de plantas medicinais até rituais mágicos.

Misticismo, medo e superstição foram pontos convergentes para todos os povos que, diante da ignorância quanto às causas das doenças, atribuíam-nas ao sobrenatural. Por castigo diante de um mau comportamento de seus protegidos ou por mero capricho, deuses, semideuses e espíritos eram considerados detentores do poder para provocar e curar as enfermidades (1). A expressão máxima da ira divina manifestava-se nas epidemias, conhecidas por "pestes" ou "pestilentias", cujo devastador poder de matar grandes contingentes populacionais causava especial terror.

A natureza de muitas das epidemias descritas na história permanece incógnita pela falta de dados sobre sinais e sintomas, sobre a evolução clínica e as condições do início e término do surto que auxiliariam a elucidar o diagnóstico. Este não foi o caso da maioria dos surtos de varíola (em sua forma major), um dos flagelos de maior mortalidade que o homem conheceu e que marcou, definitivamente, a história das Américas, em especial a do Brasil.

No presente estudo, objetivamos relatar a tragédia causada pela varíola na população colonial brasileira nos séculos XVI e XVII, partindo de uma visão voltada para a doença, para as formas de combatê-la e suas consequências para a sociedade. Portanto, foi realizada extensa revisão bibliográfica em livros de história e narrativas contemporâneas, assim como pesquisas nas fontes Scielo, Medline e Lilacs entre os anos de 1996 e 2010. Os descritores utilizados foram: História da Varíola, História da Vacina, Varíola no Brasil, Varíola/Erradicação.

\section{A DOENÇA: CAUSA, ORIGEM E DISSEMINAÇÃO}

Longo foi o caminho até que a ciência descobrisse o agente etiológico da varíola, um Orthopoxvirus. Um dos mais resistentes e maiores vírus conhecidos, ele é suficientemente grande para ser visto como um ponto no microscópio óptico. Seu genoma é uma molécula linear única de DNA de fita dupla, cujo ciclo de multiplicação é rápido e causa morte celular $(21,40)$. Desde a erradicação da varíola em 1977, este micro-organismo está confinado em dois laboratórios, um nos Estados Unidos e outro na Rússia, mas ainda hoje ele incita a preocupação mundial sobre seus efeitos em uma população não imunizada. A tragédia anunciada seria 
deflagrada por sua reexposição ao meio ambiente em um suposto ataque terrorista; a escolha deste Orthopoxvirus seria factível em razão de suas assustadoras e peculiares características (14).

Uma das propriedades mais deletérias deste vírus é sua capacidade de sobreviver em restos de crostas de pele conservadas por até um ano. Tal atributo confere-lhe uma espetacular infectividade, que não sofre influência do clima e tampouco determina predileção sobre gênero ou idade de suas vítimas. Em um passado não tão distante, determinou-se que no meio ambiente a contaminação interpessoal podia ocorrer também por contato com gotículas de saliva ou secreções respiratórias de algum indivíduo infectado (42).

$\mathrm{O}$ vírus penetrava pelas vias aéreas, multiplicava-se no local e, pelos vasos linfáticos, alcançava e se multiplicava nos linfonodos regionais. Ao atingir a corrente sanguínea, infectava baço, fígado, medula óssea e demais órgãos ricos em tecido reticuloendotelial. Nesses órgãos, multiplicava-se novamente para depois alcançar a circulação pela segunda vez $(27,43)$.

Nessa fase, manifestavam-se os pródromos da moléstia, caracterizados por febre alta, mal-estar intenso, cefaleias, dores musculares, náuseas e prostração. Na forma clínica mais branda, conhecida como minor, as manifestações clínicas eram frustas e o coeficiente de mortalidade girava em torno de $1 \%$. Na forma major, de expressões clínicas exuberantes, a vítima poderia também apresentar dores abdominais e delírios. Somente durante a segunda viremia, o agente causal atingia a pele $(27,43)$.

As lesões pontuais na pele eram a manifestação mais notável da doença; delas originou-se o nome varíola, do latim varius, pela diversidade com que se apresentavam. Essas lesões seguiam um curso evolutivo definido de mácula, pápula, vesícula, pústula, crosta e cicatriz, sempre acompanhadas por toxemia. A moléstia, também conhecida como "bexiga", podia também revelar-se de uma forma fulminante, denominada "púrpura variolosa", manifestação em que as vítimas eram rapidamente levadas à morte, sem que houvesse tempo para a erupção de lesões variólicas propriamente ditas. A pele tornava-se friável, descolava-se ou formava bolhas (27). Esta terrível apresentação da varíola estava relacionada à falta de resposta imune do doente diante da infecção viral. É possível que, nestas ocasiões, a doença tenha sido subdiagnosticada, já que não havia a presença das típicas e milenarmente conhecidas manifestações cutâneas.

Acredita-se que a varíola tenha eclodido cerca de 10 mil anos a.C., quando surgiram os primeiros assentamentos agrícolas humanos (24). Possivelmente originária da Índia, espalhou-se pela Ásia e África, tornou-se endêmica em muitas regiões e atingiu a Europa durante a Idade Média. Deixava um rastro de morte por onde passasse e, sem que fosse exceção à regra, foi atribuída ao sobrenatural nas mais diversas sociedades por ela vitimadas.

Diante de uma velha inimiga, comunidades da Ásia e África adoravam divindades provocadoras ou protetoras, como Sitala Mata (Índia), Ma-Chen e Pan-Chem (China) e Sopona (África - yorubás; no Brasil foi introduzido com os 
nomes de Omulu e Obaluaê) (25). Na Europa cristã, Deus, irado pelos pecados cometidos pelos homens, foi responsabilizado pelo envio de surtos que dizimavam de mendigos a reis. Ele também faria sentir o peso de sua fúria sobre as populações ameríndias pagãs.

No século XVIII, quando finalmente surgiu a vacina, a doença havia sido uma das maiores causas da queda populacional nativa americana e era ainda responsável pela morte de, aproximadamente, 400.000 europeus ao ano $(3,10)$.

\section{A VARÍOLA NAS AMÉRICAS E A SITUAÇÃO BRASILÍNDIA APÓS A DESCOBERTA}

Em sua marcha galopante, a varíola acompanhou o ciclo das grandes navegações e alcançou o Novo Mundo a bordo de caravelas e galeões. A perda da população nativa após o descobrimento aconteceu em um curto espaço de tempo. Se não existem dúvidas a respeito deste decréscimo, sobram discussões sobre seus números. Diferentes autores defendem uma diminuição de $25 \%$ até fastigiosos $96 \%$ no número de habitantes americanos de 1492 a 1650 (10). A despeito de não ser possível responsabilizar apenas a varíola por este tenebroso quadro, sem dúvida ela exerceu um papel importante, corroborado por relatos de sucessivas tragédias em todo o continente.

AAmérica do Sul foi integralmente contaminada até 1588 e supõe-se uma mesma relação de morbimortalidade entre os nativos de ambos os lados dos Andes: $30 \%$ a $50 \%$ dos indígenas morriam logo nos primeiros dias após o contágio $(2,17)$.

As temerosas bexigas provavelmente chegaram ao Brasil a partir de 1555, trazidas ao Rio de Janeiro pelos calvinistas franceses que haviam ali fundado um pequeno núcleo populacional (17). O sonho da França Antártica falhou por diversos e notórios motivos que não cabem ser discutidos neste artigo. Contudo, a pouco conhecida epidemia de varíola, iniciada entre os franceses e seus aliados indígenas, contribuiu para tal fracasso por ter causado a morte de vários guerreiros, um baque final para uma empreitada que já galgava o caminho do fracasso. Não existem dados sobre a real gravidade do surto, mas reconhece-se que o pior ainda estava por vir.

Uma epidemia iniciada em Portugal em 1562 teve repercussões inesperadas e trágicas em seus domínios do outro lado do Atlântico. O primeiro local atingido foi Itaparica e, em menos de um ano, a doença foi reintroduzida em Ilhéus, na Bahia. Dali se espalhou por toda a costa brasileira, em especial nos aldeamentos e missões fundados pelos jesuítas. Entre os anos de 1563 e 1564, calcula-se que nada menos de 30.000 brasilíndios tenham morrido nos primeiros 90 dias após a eclosão, mas como o surto se estendeu por vários meses, é possível que a mortalidade tenha sido ainda maior (17).

O jesuíta Leonardo do Valle, em testemunho datado de 12 de maio de 1563, denunciou a grande mortalidade em aldeamentos no Recôncavo Baiano, ao mesmo tempo em que frisava o caráter punitivo que se atribuía à doença : 
[...] seu pecado foi castigado por uma peste tão estranha que por ventura nunca nestas partes houve outra semelhante [...] a mortandade era tal que havia casa que tinha 120 doentes e a uns faltavam já os pais, a outros os filhos e parentes e, o que pior é, as mães, irmãs e mulheres, que são as que fazem tudo [...] faltando elas não havia quem olhasse pelos doentes [...] havia muitas mulheres prenhes que tanto que lhes dava o mal as debilitava de maneira que botavam a criança [...] e destas prenhes quase nenhuma escapava por toda a terra, nem menos as crianças [...] Finalmente chegou a coisa a tanto que já não havia quem fizesse as covas e alguns se enterravam [...] arredor das casas e tão mal enterrados que os tiravam os porcos [...] o que é mais para doer, que muitos morriam sem confissão e sem batismo, porque era impossível acudirem dois padres a tanta multidão... se morriam 12, caiam 20 [...] Bem me parece que em cada uma daquelas três aldeias morreria a terceira parte da gente porque só em Nossa Senhora da Assunção haverá dois meses que ouvi dizer que eram mortas 1080 almas, e com tudo isso diziam os índios que não era nada em comparação da mortalidade que ia pelo sertão adentro [...]. (8)

O episódio narrado por Vale, com um tom de frustração por não ter havido tempo para a cristianização de muitas vítimas, esteve longe de ser o único. Medo, desespero e morte foram registrados em novo surto que atingiu o Espírito Santo em 1565. Ali os jesuítas testemunharam uma mortalidade tão alta que, segundo eles, uma mesma moradia podia servir como enfermaria para os doentes e cemitério para os mortos (6).

Em todos os relatos, havia o senso comum sobre o caráter punitivo da doença e, por este motivo, atribuía-se a eclosão das epidemias à interferência divina, fosse entre os indígenas, que andavam nus, alimentavam-se de carne humana e, sobretudo, eram pagãos, ou entre os franceses que, apesar de cristãos, representavam perigo aos domínios lusitanos.

Em 1597, naus francesas teriam invadido e saqueado o castelo português de Arguim, na costa da África, e roubado a sagrada imagem de Santo Antônio. Com seus inimigos vitimados pela varíola, os portugueses apressaram-se em atribuí-la como penitência dos céus. Doentes e sob provações a bordo de suas embarcações, estes mesmos franceses aportaram em terras brasileiras. Assim, causaram um novo e avassalador surto, cujas maiores vítimas foram, novamente, os indígenas (37).

A despeito de a varíola atingir também a população de origem europeia e africana, maiores índices de mortalidade pendiam sempre para o lado nativo. Donos de um sistema imune incapaz de reconhecer e combater o vírus letal, muitos indígenas teriam sucumbido diante de formas clínicas graves da doença, como a major, ou particularmente a mais atroz e relacionada à baixa imunidade - a púrpura variolosa. Descrições como a de Leonardo do Vale sugerem a presença 
marcante da púrpura, cujo quadro clínico estaria, muitas vezes, sobreposto a infecções bacterianas secundárias. Assim, na ausência das típicas lesões variolosas, os religiosos não arriscavam um diagnóstico definitivo: "Há de quando em quando entre eles [índios] como aconteceu pouco tempo há, que pedaços lhes caíam, com grandes dores e um cheiro peçonhentíssimo [...]" (5).

Às epidemias seguia-se o drama da fome, pois não havia quem pudesse cultivar a terra, e a desnutrição atingia principalmente a população brasilíndia.

A incapacidade dos pajés em combater os males trazidos pelos europeus e africanos foi uma das armas usadas pelos jesuítas para a sua desmoralização. Relegados a um segundo plano, desmistificados quanto às suas funções, os pajés passaram a ser desprezados e até expulsos pelos demais membros de sua tribo: “ [...] vós, sim, padres, viveis e não nossos feiticeiros que morrem como nós [...]"(33).

Os aldeamentos e missões jesuíticas tiveram marcante participação na população nativa por surtos epidêmicos, apesar de involuntária. Ao passarem a viver em aglomerações e por esta razão em condições comprometidas de higiene - como eram as demais instalações europeias da época -, os indígenas tornaram-se um alvo fácil para doenças infectocontagiosas (16). Assim, muitas destas missões resultaram em fracasso.

Apenas durante o século XVI, os redutos jesuíticos no Recôncavo Baiano sofreram sensível arrefecimento, como as aldeias de São Paulo (Brotas), Itaparica, São Miguel de Taperaguá e de São Miguel de Tapepitanga (20). Nelas, a população morreu pela varíola ou fugiu de suas consequências, como a fome e o medo de novos surtos. Os sobreviventes partiam para o interior e, invariavelmente, levavam consigo o vírus maléfico.

Desta forma, falhava todo um esquema para a incorporação dos nativos à sociedade colonial. Não interessava aos colonizadores, em especial à Metrópole, a alta mortandade indígena pela varíola ou qualquer outra doença que os levasse à morte. Afinal, eles eram seus escravos para os mais diversos serviços, sua mão de obra nas lavouras de cana, seus guias através dos sertões, seus soldados na defesa das fronteiras e sua redenção perante a Igreja e o Papa. A exceção estava nas ocasiões em que a doença vitimasse alguma tribo inimiga que não pudesse ser dominada.

As lutas travadas entre os portugueses e algumas tribos indígenas por eles não subjugadas foram sangrentas e resultaram em muitas mortes para ambos os lados. A situação para os colonizadores complicava-se particularmente quando se formavam confederações. Numericamente superiores e lutando contra armas de fogo cujo poder de matar estava aquém das centenas de flechas que podiam ser lançadas ao mesmo tempo em que se disparava um tiro de arcabuz, os nativos apresentavam-se em notória vantagem. Contudo, tal qual acontecera com os demais indígenas americanos, surtos variólicos acabaram por alcançá-los e o resultado foi a inversão do desfecho de muitas batalhas cuja vitória nativa parecia certa (20). Os maiores exemplos são encontrados em narrativas de acontecimentos no Nordeste do Brasil. 
Ao invadir o território ocupado pelos Potiguares, que viviam espalhados em 50 aldeias da Paraíba até o Maranhão, os portugueses encontraram uma resistência obstinada. Anos de lutas não foram suficientes para subjugá-los e, em 1597, os colonizadores tiveram de enfrentar mais um entre seus numerosos problemas - a varíola. Com suas tropas desfalcadas, eles foram forçados à retirada e os sobreviventes voltaram à Paraíba deixando insepultas as vítimas da doença. $\mathrm{O}$ que de início parecia uma imensa desvantagem foi crucial para a inversão do quadro. O contato com a pele, secreções ou roupas dos inimigos infectados foi suficiente para o contágio indígena. Em pouco tempo, os nativos, dizimados, desapareceram em extensas regiões outrora consideradas seus redutos intransponíveis. A seguinte investida militar portuguesa na barra de Natal (Rio Grande do Norte) mostrou-se surpreendentemente tranquila, o que em nada indicava a temida e tenaz ferocidade de seus ocupantes originais $(23,29)$.

Após resistirem militarmente por 25 anos, o povo Potiguar rendeu-se aos portugueses, aniquilado pela moléstia. Os poucos sobreviventes exaustos, famintos e desorientados acabaram recrutados na luta contra outra tribo hostil, os Aimorés $(23,29)$. Estes seguiram destino semelhante e tombaram, do mesmo modo, diante da varíola.

\section{PROBLEMAS NA ECONOMIA COLONIAL: A VARÍOLA NOS CAMPOS E CIDADES}

Os jesuítas cedo reconheceram que grandes faixas de despovoamento se formavam e que parte da culpa cabia à escravização em massa praticada pelos colonizadores, além da alta mortalidade nativa pelas doenças infectocontagiosas. Da mesma forma, testemunharam a fuga para o interior à procura de liberdade - e saúde - e o abatimento geral que tomou conta das sociedades indígenas.

[...] Pelo que os pobres brasis, como de sua natureza são tristes e coitados, entraram em tamanha melancolia, que os mais deles morreram e se consumiram, outros fugiram pela terra dentro e não pararam senão dali a cento e duzentas léguas, e deixaram a fralda do mar despovoada.

Durante a invasão holandesa, os batavos relataram que entre 1645 e 1646 dificilmente conseguiriam mobilizar 300 guerreiros na capitania do Rio Grande (do Norte), ao passo que 80 anos antes os números seriam da ordem de 100 mil. O próprio Brasil holandês assistiu impotente a uma das epidemias de bexigas que alcançou a Bahia em 1641 e logo depois o Rio de Janeiro. O surto teria começado entre escravos importados do Quilombo dos Corvos, lugar da África Central assim designado pelo grande número daquelas aves ali encontradas após uma grande epidemia $(2,38)$. 
A importação de escravos oriundos de regiões endêmicas era a principal via de chegada da varíola nas Américas. Apinhados em condições deploráveis nos navios negreiros, os africanos que conseguiam sobreviver à travessia atlântica eram uma importante fonte de transmissão das mais diversas doenças infectocontagiosas. Formou-se, assim, um cruel círculo de causa e efeito: quanto mais indígenas morriam, maior se tornava a necessidade de mão de obra africana que, doente, disseminava no Novo Mundo epidemias avassaladoras (16).

Para a empresa colonial, tamanha mortandade era inadmissível. As lavouras de cana e a produção de açúcar nos engenhos espalhados pela costa paravam por causa da falta de mão de obra. A economia ruía. Em 1617, um requerimento entregue ao governador D. Luis de Sosa pela Câmara de Olinda, em nome dos moradores, lavradores e senhores de engenho de Pernambuco, solicitava moratória do pagamento de suas dívidas por motivo da epidemia de bexigas que destruíra as plantações - uma clara alusão à extensão da tragédia que se instalara(22).

Outras atividades econômicas regionais igualmente rentáveis também passavam a enfrentar dificuldades. São Paulo, cuja economia era baseada principalmente na captura de escravos indígenas, precisou mudar as táticas de apresamento: se no século XVI elas se restringiam às imediações do rio Tietê (São Paulo), a partir da drástica diminuição no número de nativos, entradas e bandeiras alastraram-se pelos sertões à procura dos Guaranis e, forçosamente, passaram a integrar o circuito comercial intercapitanias (28). Em 1637, registravam-se invasões paulistas na região dos Patos (Rio Grande do Sul), com aprisionamento de 70.000 a 80.000 almas. Tais incursões resultavam na propagação de doenças a populações que já haviam fugido de seus algozes e respectivos males. Na região do Prata, apenas 1.000 dos 7.000 escravizados teriam sobrevivido ao apresamento (7).

Sem controle sobre a doença, o século XVII testemunharia outros desastrosos surtos variólicos, como os de 1621, 1631, 1642, 1662-1663, 1665-1666 e 1680-1684, todos iniciados nas capitanias ao norte, então o principal polo econômico do país. Em 1695, descreveu-se a primeira epidemia em área correspondente ao atual estado do Rio Grande do Sul, mas, em razão da grande extensão do mal em episódios anteriores, é provável que outras tenham acontecido antes desta $(9,17)$.

A despeito de esses surtos serem sentidos principalmente nos campos, principal agente da economia colonial, as pequenas e incipientes vilas e cidades brasileiras também sentiam seus efeitos nefastos. Na grande epidemia que atingiu Salvador (Bahia) em 1666, descrita por Sebastião da Rocha Pitta (1660-1738), foi registrado que casas com 40 ou 50 moradores não continham uma só pessoa sã. Crédula, rodeada por uma alta mortandade, a população lotava as igrejas em busca de perdão pelos pecados cometidos e aumentava ainda mais a possibilidade de contágio (35).

Nesta mesma epidemia de 1666 e em outras que a antecederam e sucederam, observava-se a total ineficácia das ações governamentais quanto ao 
combate, ao amparo às vítimas e à implantação de medidas profiláticas eficazes. Quando chegou a Santos, a Câmara da vila de São Paulo alardeou sobre os perigos de contágio, pois a epidemia espalhara-se por toda a costa. Ordenou-se a formação de um cordão sanitário em localidades próximas de Cubatão e no Alto da Serra e foi preciso entrar em litígio com a Câmara de Mogi das Cruzes pelo não cumprimento das ordens preventivas. Tal contenda entre as Câmaras, que hoje pertenceriam ao estado de São Paulo, não foi exceção: as tentativas de implantar medidas profiláticas para impedir epidemias que chegavam pelo mar resultavam em fracasso, descumpridas tanto por membros mais abastados da sociedade quanto pelo clero e povo. Cartas e gêneros alimentícios, em especial o sal, eram contrabandeados entre o planalto e o litoral sem uma repressão efetiva, apesar das tentativas de conter o incômodo intercâmbio. As penas para aqueles que quisessem alcançar Cubatão ou Santos era uma multa de 200 cruzados ou cadeia de 30 dias para os que não pudessem pagá-la, mas até a ameaça de degredo de quatro anos para Angola chegou a ser aventada. Como medida extraordinária e em vão, guardas tinham ordens de atirar contra aqueles que pretendessem forçar a passagem pelo Caminho do Mar. Diante do fracasso destas tentativas desesperadas, a varíola irrompeu na vila de São Paulo e sua Câmara passou a aconselhar os vizinhos para que não a visitassem "[...] pera que asin se evitassen os danos que podiam vir a esta dita vila [...]" (41).

Sem domínio sobre a varíola, sem guarida e crente de sua culpa, a população valia-se da proteção divina. Em cada casa se ouviam rezas e ladainhas sob a queima de velas e incensos, que tinham o inebriante efeito de acalmar os aflitos. Afinal, desde os seus primórdios, o Brasil não possuía médicos suficientes que atendessem sua espalhada população e a falta de assistência humana conduzia a um inevitável apelo ao divino(16).

\section{AS TENTATIVAS DE TRATAMENTO E PREVENÇÃO}

Lutava-se contra a varíola com as armas consideradas apropriadas, e o valor simbólico da terapêutica tomava ainda maior relevância. Assim, nas receitas coloniais, de médicos ou leigos, não faltavam grandes doses de excremento de cavalo, pulverizado e tomado com qualquer líquido, usado por ser proveniente de um animal que, pela sua constituição física, transmitia a ideia de força e vigor (39). Nas Coleções de Várias Receitas, cuidadosamente elaboradas pelos jesuítas e publicadas no século XVIII, além de excremento equino fresco, recomendava-se a mistura de papoulas vermelhas (usadas como sudorífero, narcótico e antiespasmódico), bezoártico do Curvo (preparado que continha cálculos extraídos do sistema digestivo de animais), arrobe de bagas de sabugo (considerado sudorífero e contraveneno nas chamadas febres malignas) e água comum (4).

O uso de substâncias estranhas e repugnantes foi muito comum na Europa até o advento da medicina científica. A origem desta peculiar terapêutica remonta à Antiguidade e era muito utilizada por sumerianos, assírios, egípcios e, em 
menor proporção, por gregos e romanos. As formulações terapêuticas continham substâncias muito diversas e incluíam vegetais, animais (tecidos, órgãos ou animais inteiros, que podiam ser triturados ou carbonizados), fezes e urina (de origem animal ou humana); poucos ou muitos desses elementos eram incluídos em uma só receita. Era a chamada Dreckapotheke (em alemão, farmácia de excrementos) que, trazida ao Brasil pelos colonizadores, associou-se à tradicional medicina indígena, particularmente rica no uso de plantas medicinais (15). Havia uma peculiaridade na aceitação deste tipo de tratamento além de seu valor simbólico: a crença da cura punitiva. Como a culpa da doença era atribuída ao próprio doente, o uso de substâncias abjetas justificava-se por promover o sofrimento por meio do qual este pecador se livraria de seus males. Desta forma, quanto mais amargo e doloroso fosse o remédio, melhor efeito ele teria (34).

Contra a varíola, a virulência de suas manifestações fazia com que o arsenal terapêutico parecesse ainda mais limitado. Além da Dreckapotheke e das sempre presentes rezas e sangrias, incluíam-se os banhos quentes. Nos aldeamentos e missões jesuíticos, as vítimas com febre e dores lancinantes eram submetidas à remoção cirúrgica da pele que se desprendia de seus corpos(16).

Não há indícios de que tenha sido praticada a variolização no Brasil nos primeiros dois séculos após o descobrimento. A despeito de ser de conhecimento milenar entre os povos orientais, esta técnica chegou à Europa somente no início do século XVIII pelas mãos de Lady Mary Montagu. A corte real inglesa interessou-se pelo método, que passou a ser chamado de bizantino em alusão a Bizâncio (Constantinopla, atual Istambul), local onde a nobre dama havia observado seus efeitos. Na variolização, pessoas sadias eram expostas a material retirado de lesões variolosas humanas, tal procedimento baseava-se na constatação de que os sobreviventes a esta forma de contágio não estavam sujeitos a novas infecções. A técnica, entretanto, acarretava altos índices de mortalidade, já que o inoculado poderia desenvolver diferentes manifestações da doença, mesmo se o material das pústulas variolosas tivesse sido obtido de indivíduos com a forma branda da varíola(13).

Diante da mortal ameaça da doença sobre seus protegidos, o padre carmelita José da Magdalena teria praticado a variolização pela primeira vez no Brasil por volta de 1720. O religioso, superior das Missões do Rio Negro (Pará) que incluíam 26 povoações, iniciou a prática entre os indígenas. Desta forma, segundo informações da época, o religioso teria poupado a vida de um bom número de nativos (31). La Condamine, que testemunhou os efeitos nefastos da epidemia que atingiu o baixo Amazonas em 1743, lamentou que tal técnica não tivesse sido usada entre os índios cativos naquele momento e enfatizou:

Há 15 ou 16 anos antes um missionário carmelita das cercanias do Pará, vendo todos os seus índios morrerem um após o outro, e tendo sido informado pela leitura de um jornal do segredo da inoculação, que tanto 
estardalhaço fazia na Europa [...] ousou mandar inocular a varíola em todos os índios que ainda não haviam sido atacados e não perdeu um sequer [...]. (18)

\section{CONSIDERAÇÕES FINAIS}

Por centenas, senão milhares de anos, a varíola foi um dos flagelos que mais atingiu a humanidade. Quando o vírus causador cruzou o Atlântico e se instalou no Novo Mundo, desencadeou uma das maiores tragédias conhecidas em toda a história.

De início transmitida de maneira involuntária, a varíola e suas nefastas consequências entre os indígenas não interessavam ao governo português. Afinal, sua própria população era pequena, em número insuficiente para um grande projeto de colonização, e sofria com surtos epidêmicos de sarampo, tifo exantemático, peste bubônica e a própria varíola (36).

O território americano a conquistar e manter era enorme e, mais interessante que despovoá-lo, era suprir sua necessidade de mão de obra para a agricultura (crises de fome eram recorrentes após surtos epidêmicos pela falta de mãos nas lavouras), firmar alianças militares e garantir a posse das novas terras. Neste último contexto, um parecer do Conselho Ultramarino de 1695 concedeu aos brasilíndios a alcunha de "Muralhas dos Sertões" e os transformou em guerreiros a serviço da Coroa lusitana (12).

Contudo, a dura realidade dos trópicos e o conhecimento de que roupas de variólicos podiam transmitir a doença fizeram com que colonos utilizassem a varíola como arma contra indígenas hostis. As roupas que continham restos de pele contaminados pelo vírus eram propositadamente expostas ao relento e recolhidas sob os curiosos olhares nativos $(26,30)$. $\mathrm{O}$ aniquilamento destas tribos ao mesmo tempo em que abria caminho para a colonização europeia fomentava ainda mais o tráfico de escravos negros.

$\mathrm{Na}$ África, a varíola era endêmica e, quando seu território era assolado por grandes secas, a desestruturação social e a fome que se seguiam propiciavam a captura mais fácil de escravos e o aparecimento de epidemias. Desta forma, um problema climático no continente negro relacionava-se a períodos de maior tráfico de africanos e maior transmissão da varíola nas terras carentes de mão de obra (11).

Trazida a bordo de embarcações vindas da Europa e África, usada como arma biológica e causa de graves implicações econômicas e sociais, a história da varíola confunde-se com a própria história das Américas e, particularmente, do Brasil. As consequências nefastas de sua presença constituíram o derradeiro delineamento de todo o continente e uma das causas, senão a principal, de sua conquista. Afinal, diante da falta de imunidade indígena contra doenças trazidas de além-mar, as guerras tencionadas ou de fato travadas contra os colonizadores já estavam perdidas, antes de iniciadas. 


\section{REFERÊNCIAS}

1. Ackerknecht EH. Medicina y Antropologia Social. Estudios Vários. Traducción Castellana ampliada. Madrid, Akal Editor, 1985.

2. Alencastro LF. O Trato dos Viventes: Formação do Brasil no Atlântico Sul. Companhia das Letras, São Paulo, 2000.

3. Braudel F. As Estruturas do Cotidiano. Civilização Material, Econômica e Capitalismo Séculos XV a XVIII. Martins Fontes Editora, São Paulo, 1997.

4. Calainho DB. Jesuítas e Medicina no Brasil Colonial. Tempo 10: 61-75, 2005.

5. Carta de Baltazar Fernandes ao Colégio de Coimbra. 05/12/1567. In: Monteiro JM. Negros da Terra. Índios e Bandeirantes nas Origens de São Paulo. São Paulo, Companhia das Letras. $2^{\mathrm{a}}$ Reimpressão, 1994.

6. Carta Jesuítica. In: Nemesio V. O Campo de São Paulo. A Companhia de Jesus e o Plano Português do Brasil. Lisboa $3^{\text {a }}$ Edição. 1971.

7. Carta de Lourenço de Mendonça (referindo-se à expedição de Luis Dias Leme). "Súplica a sua Majestade". 1637. IHGB, lata 219.doc 17. In: Monteiro, JM. Negros da Terra. Índios e Bandeirantes nas Origens de São Paulo. São Paulo, Companhia das Letras. 2a Reimpressão, 1994.

8. Cartas Avulsas (1550-1568). Carta do Padre Leonardo do Valle da Bahia para o Padre Gonçalo Vaz, Provincial da Companhia de Jesus de Portugal, aos 12 de Maio de 1563. Rio de Janeiro: Imprensa Nacional, 1887. Fac-simile do rosto do livro "Cartas Avulsas", edição impressa e não publicada.

9. Crosby Jr W. Imperialismo Ecológico. A Expansão Biológica da Europa. 900-1900. São Paulo, Companhia das Letras, 1998.

10. Cunha MC. Introdução à História Indígena. http://hemi.nyu.edu/course-rio/perfconq04/materials/ text/intro_hist_indig.htm Acesso em 23/07/2008.

11. Dauril A, Miller J. In: Chalhoub S. Cidade Febril. Cortiços e Epidemias na Corte Imperial. São Paulo, Companhia das Letras, 1996.

12. Farage N. As Muralhas dos Sertões: os Povos Indígenas no Rio Branco e a Colonização. Dissertação de Mestrado - Unicamp, 1996.

13. Fernandes T. Vacina Antivariólica: seu Primeiro Século no Brasil (da Vacina Jenneriana à Animal). Hist Cienc Saúde - Manguinhos, 6: 29-51, 1999.

14. Fiocruz. Glossário de Doenças - Varíola http://www.fiocruz.br/ccs/cgi/cgilua.exe/sys/start. $\mathrm{htm}$ ?infoid $=310 \&$ sid $=6$ Acesso em 7 de fevereiro de 2010.

15. Gurgel CBFM, Lewinsohn R. Índios, Jesuítas e Bandeirantes. O uso das Plantas Medicinais no Brasil Colonial. Anais de História de Além Mar X: 113-127, 2009.

16. Gurgel C. Doenças e Curas. O Brasil nos Primeiros Séculos. São Paulo, Editora Contexto, 2010.

17. Hopkins DR. Princes and Peasants. Chicago and London, The University of Chicago Press, 1983.

18. La Condamine CM de. Viagem pelo Amazonas 1735-1745. Rio de Janeiro, Nova Fronteira; São Paulo, Edusp, 1992.

19. Le Goff J. As Doenças têm História. Lisboa, Terramar, 1985.

20. Leite S. História da Companhia de Jesus no Brasil. In: Hoornaert E, Azzi R, Grijp KVD, Brod B. História da Igreja no Brasil. Tomo II/1; 4ª . Edição. Petrópolis, Edições Paulinas, 1992.

21. Levinson W, Jawest E. Microbiologia medica e imunologia. 7.ed., Porto Alegre, Artmed, 2005.

22. Livro Primeiro do Governo do Brasil (1607-1633). Ministério das Relações Exteriores. Seção de Publicações do Serviço de Documentação. Departamento de Imprensa. Rio de Janeiro. 1958.

23. Luna L. A Resistência do Índio à Dominação do Brasil. Rio de Janeiro, Editora Leitura, 1981.

24. Martelli CMT. Dimensão Histórica das Epidemias. Rev Patol Trop 6: 1-8, 1997.

25. Martins RA. A Varíola e a Descoberta da Vacinação. In: Contágio. História da Transmissão das Doenças Transmissiveis. Capítulo 7. Disponível em: http://www.ifi.unicamp.br Acesso em 20/04/2008.

26. Martius KFP. Natureza, Doenças, Medicina e Remédios dos Índios Brasileiros (1844). São Paulo, Companhia Editora Nacional, 1939.

27. Ministério da Saúde. Guia de vigilância epidemiológica. $6^{\text {a }}$ edição, Brasília, DF, 2007. 
28. Monteiro JM. Negros da Terra. Índios e Bandeirantes nas Origens de São Paulo. São Paulo, Companhia das Letras. $2^{\text {a }}$ Reimpressão, 1994.

29. Moonen F. Pindorama Conquistada. Repensando a Questão Indígena no Brasil. João Pessoa, Editora Alternativa, 1983.

30. Ofício do Ouvidor da Comarca de Ilhéus Balthasar da Silva Lisboa para Rodrigo de Souza Coutinho no qual the communica uma interessante informação sobre a comarca de Ilhéus, a sua origem, a sua agricultura, comércio, população e preciosas matas. Cairu, 20 de Março de 1799. Anais da Biblioteca Nacional 36: 106-127, 1914.

31. Prat Fr A. Notas Históricas sobre as Missões Carmelitas no Extremo Norte do Brasil Séculos XVII a XVIII. Recife, 1941.

32. Relação das Coisas que Fizeram os Padres da Companhia de Jesus nas suas Missões do Japão, China, Tidore, Ternate, Ambóino, Malaca, Pegu, Bengala, Maduré, Costa da Pescaria, Manar, Ceilão, Travancor, malabar, Sodomala, Goa, Salcete, Lahor, Diu, Etiópia a alta ou Preste João, Monomotapa, Angola, Guiné, Serra Leoa, Cabo Verde e Brasil nos anos de 1600 a 1609 e do processo da conversão e cristandade daquelas partes: tiradas das cartas que os missionários de lá escreveram. Padre Fernão Guerreiro. Tomo I. 1600 a 1603. Coimbra, Imprensa da Universidade. Livro Quarto. Capítulo Primeiro. 1930.

33. Rezende MLC. Entre a Cura e a Cruz. Jesuítas e Pajés nas Missões do Novo Mundo. In: Artes e Oficios de Curar no Brasil. Chalhoub S, Marques VRB, Sampaio GR, Galvão Sobrinho CR (orgs). Campinas, Editora Unicamp. 2003.

34. Ribeiro MM. A Ciência dos Trópicos: a Arte Médica no Brasil do século XVIII. São Paulo, Editora HUCITEC, 1997.

35. Rocha Pitta S. História da América Portuguesa. Bahia, Imprensa Econômica. 1878.

36. Rodrigues T. Crises de Mortalidade em Lisboa nos Séculos XVI e XVII. Lisboa, Livros Horizonte, 1990.

37. Santos Filho L. Historia Geral da Medicina no Brasil. São Paulo, Editora da Universidade de São Paulo, 1977.

38. Schatzmayr HG. A Varíola, uma antiga inimiga. Cad Saúde Pública 17: 1525-1530, 2001.

39. Southey R. História do Brasil. Volume I. $4^{a}$ Edição Brasileira. São Paulo, Edições Melhoramentos, 1977.

40. Strohl WA, Rouse H, Fishers B, Harvey RA(Co-ord), Champe P (co-ord). Microbiologia Ilustrada. Porto Alegre, Artmed, 2004.

41. Taunay AE. A Varíola e o Sarampo. Anais do Museu Paulista. Tomo 3. Diário Oficial de São Paulo, 1927.

42. Veronesi R. Doenças Infecciosas e Parasitárias. $7^{\text {a }}$ Edição. Rio de Janeiro, Editora Guanabara Koogan, 1982.

43. Veronesi R, Focaccia R. Tratado de infectologia. vol. 1. 3.ed. Editora Atheneu. 2005. 
